\title{
Saint-Maur - Créneau de dépassement RN 143
}

$\mathrm{n}^{\circ} 064519$

Marie-Paule Clément-Pallu de Lessert

\section{(2) OpenEdition}

Journals

Édition électronique

URL : http://journals.openedition.org/adlfi/14088

ISSN : 2114-0502

Éditeur

Ministère de la culture

Référence électronique

Marie-Paule Clément-Pallu de Lessert, "Saint-Maur - Créneau de dépassement RN 143 », ADLFI.

Archéologie de la France - Informations [En ligne], Centre, mis en ligne le 03 mars 2015, consulté le 19 avril 2019. URL : http://journals.openedition.org/adlfi/14088

Ce document a été généré automatiquement le 19 avril 2019

(C) Ministère de la Culture et de la Communication, CNRS 


\title{
Saint-Maur - Créneau de dépassement RN 143
}

$n^{\circ} 064519$

\author{
Marie-Paule Clément-Pallu de Lessert
}

Lien Atlas (MCC) :

http://atlas.patrimoines.culture.fr/atlas/trunk/index.php?

ap_theme=DOM_2.01.02\&ap_bbox=1.556;46.737;1.685;46.853

1 Les sondages effectués sur environ $3 \mathrm{~km}$ se sont révélés en grande partie négatifs, toutefois il faut noter la présence de mobilier, daté de l'âge du Bronze, colluvionné dans certaines tranchées. Ce mobilier semble provenir d'une légère hauteur utilisée actuellement comme carrière.

\section{INDEX}

Index géographique : Centre, Indre (36), Saint-Maur

Index chronologique : âge du Bronze

Mots-clés : mobilier

operation Évaluation archéologique (EV) 